\title{
ASSESSMENT OF NUTRIENTS LEVELS IN GROUNDWATER WITHIN THE LOWER PRA BASIN OF GHANA
}

\author{
M. K. Dorleku*, A. O. Affum, C. K. Tay and D. Nukpezah \\ (M. K. D. \& C. K. T.: CSIR- Water Research Institute, P.O Box AH 38 Achimota; A. O. A.: \\ National Nuclear Research Institute, Ghana Atomic Energy Commission P.O Box LG 80, \\ Legon; D. N.: Institute of Environmental Studies and Sanitation, \\ University of Ghana, Legon, Accra, Ghana). \\ Corresponding author's email: mdorleku@hotmail.com
}

\begin{abstract}
The level of concentration of nitrates, phosphates, and sulphates was determined in groundwater within the Pra Basin to ascertain the degree of anthropogenic influence via the application of fertilizer and other agro-chemical to farmlands by farmers. Sixty-five (65) boreholes in forty-five (45) communities were analysed between January and April 2012 to cover the dry season and between June and October 2012 to cover the wet season. The results show that nitrate for both seasons range between $0.011 \mathrm{mg} / \mathrm{l}$ and $5.01 \mathrm{mg} / \mathrm{l}$ and therefore within the WHO (2006) guideline value of $10 \mathrm{mg} / \mathrm{l}$, whilst that of phosphate range between $0.01 \mathrm{mg} / \mathrm{l}$ and 3.08 $\mathrm{mg} / \mathrm{l}$ and therefore outside the USEPA guideline value of $2.5 \mathrm{mg} / \mathrm{l}$. Sulphate recorded a range between 1.60 and $96.2 \mathrm{mg} / \mathrm{l}$ and therefore within the WHO (2006) guideline value of $250 \mathrm{mg} / \mathrm{l}$. The concentration levels of the two nutrients of the parameters, nitrates and phosphate were correlated against borehole depth and the results show a weak positive and negative correlation for nitrate and phosphate respectively. There was thus, an indication that the levels of all parameters, nitrate, phosphate and sulphate are not yet a threat to groundwater in the basin.
\end{abstract}

Keywords: Groundwater, Nutrients, Fertilizer application, Agrochemicals, Biogeological processes

\section{Introduction}

Globally, the safety and quality of water are essential, especially to human health, agriculture, aquaculture, industry and all forms of life. Over the last few years, groundwater resource has become the principal source of domestic water supply in many countries of the world including Ghana (Hynds et al. 2014). The preference of groundwater over surface water as a source of drinking water is based on the fact that groundwater excluded from the atmosphere would be less susceptible to pollution (Kortatsi, 2006; Smedley et al., 1995). This is true to an extent. However, groundwater in hard-rock aquifers, particularly in mining areas, is known to be vulnerable to quality problems that may have serious impact on human health as a result of carbonate deficient rocks that give rise to poorly buffered waters (Smedley et al., 1995). It has been reported that many public health surveys and water quality analyses have shown that groundwater is not immune to a wide range of contaminants including nutrients such as nitrates and phosphates (Asamoah \& Amorin, 2011).

Nutrients are essential for healthy plant and animal populations and provide a range of 
benefits, including increased food production for a growing global population. However, too much nutrient can have adverse effects on water quality, drinkingwater sources, recreation, and aquatic life (USGS, 2010). Effective crop production depends on an adequate supply of nutrients to the crops through fertilizer application to achieve maximum yield. However, soil nutrients need to be managed properly to meet the fertility requirements of crops without adversely affecting the quality of our valuable water resources. On a typical dairy farm, all nutrients are cycled from the soil to crops, to animals, and finally back to the soil as manure. However, nutrient recycling on almost all farms is not a closed-loop system and nutrients leave the farm in various ways and lost into the environment through soil erosion, phosphorus runoff, nitrogen leaching, and manure ammonia volatilization which not only make nutrient cycling inefficient but also impose negative impacts on water quality. (CAFÉ, 2017).

The inorganic contaminant of greatest concern in groundwater is the nitrate ion, $\left(\mathrm{NO}_{3}^{-}\right)$which commonly occurs in both rural and suburban aquifer (Baird \& Cann, 2008). Excessive nitrate in drinking water can lead to methemoglobinemia also known as "blue-baby syndrome," in which oxygen levels in the blood become too low, sometimes with fatal results (Baird \& Cann, 2008; USGS, 2010). Concentrations of dissolved phosphorus in groundwater typically are low because phosphorus tends to sorb to soil and aquifer sediments and is not readily transported in groundwater (Holman et al. 2008) The principal sources of phosphorus to groundwater systems include overlying soils, dissolution of minerals that contain phosphate in aquifer sediments, agricultural fertilizer, animal waste, and leaking septic systems or infiltration of wastewater (Fuhrer et al.1999). The Pra Riv- er and its tributaries constitute a major source of water supply to communities within the basin. The major tributaries are perennial and constitute all-year-round reliable water source and recharge resource for groundwater (WRC, 2010). The Pra Basin is one of the most extensively and intensively used river basin areas in Ghana in terms of settlement, agriculture, logging and mining (WRC, 2010). The basin contains most of the large cocoa growing areas in the Eastern, Ashanti, and Central regions. Tree cash crop cultivation other than cocoa includes mainly oil palm with a lot of large commercial plantations (WRC, 2010). Also, food crops such as cassava, yam, cocoyam, plantain, as well as fruits such as banana, oranges, etc, are produced together with cocoa for subsistence with the use of inorganic fertilizers and other agrochemicals (Tay et al., 2013; Tay, 2015). Knowledge on the possible future threat posed by nutrient pollution such as nitrate and phosphate as a result of the use of inorganic fertilizers and agrochemicals for purposes of farming within the basin is limited. However, Ahialey et al, (2010); Tay et al., (2013) did some work on general routine water quality within the ba$\sin$. It is for this reason that this paper seeks to identify the level and source of nutrient pollution on the groundwater as well as any possible health hazards associated with it.

\section{Experimental}

\section{Study area}

The Lower Pra Basin lies within $05^{\circ} 00^{\prime} 0$ " and $06^{\circ} 0{ }^{\prime} 00^{\prime \prime} \mathrm{N}$ and $01^{\circ} 0$ ' $00^{\prime \prime}$ and $02^{\circ} 0{ }^{\prime} 00^{\prime \prime}$ (Fig.1). The climate is sub-equatorial wet, with two rainy seasons (May-July and SeptemberNovember) (Dickson \& Benneh 2004). The mean annual rainfall is relatively high, about $1,500 \mathrm{~mm}$ but is also very variable, ranging between $1300 \mathrm{~mm}$ and $1900 \mathrm{~mm}$. The basin is 
warm and moist throughout most of the year. The relative humidity is between $70 \%-80 \%$ throughout the year (Dickson \& Benneh 2004). In the drier seasons, temperatures are around $26^{\circ} \mathrm{C}$ in August and $30^{\circ} \mathrm{C}$ in March (WRC, 2012). It is made up of four major tributaries namely the Ofin, Oda, Anum and Birim. These tributaries merge into the lower Pra which then flows into the Gulf of Guinea through its estuary at Shama (GWSC, 1989). The basin lies completely within the forest ecological zone of Ghana and has a moist semi-deciduous forest with valuable timber species (Dickson $\&$ Benneh 2004). Owing to the development of the cocoa industry, the initial forest has been modified to a secondary forest consisting of shrubs, soft woody plants and climbers (Dickson \& Benneh, 2004). The basin is principally dominated by the forest ochrosols, and to a lesser extent, forest ochrosol-oxysol intergrade (Dickson \& Benneh, 2004; GWSC, 1989). The orchrosols are highly coloured soils with little leaching characteristics (Dickson \& Benneh, 2004).

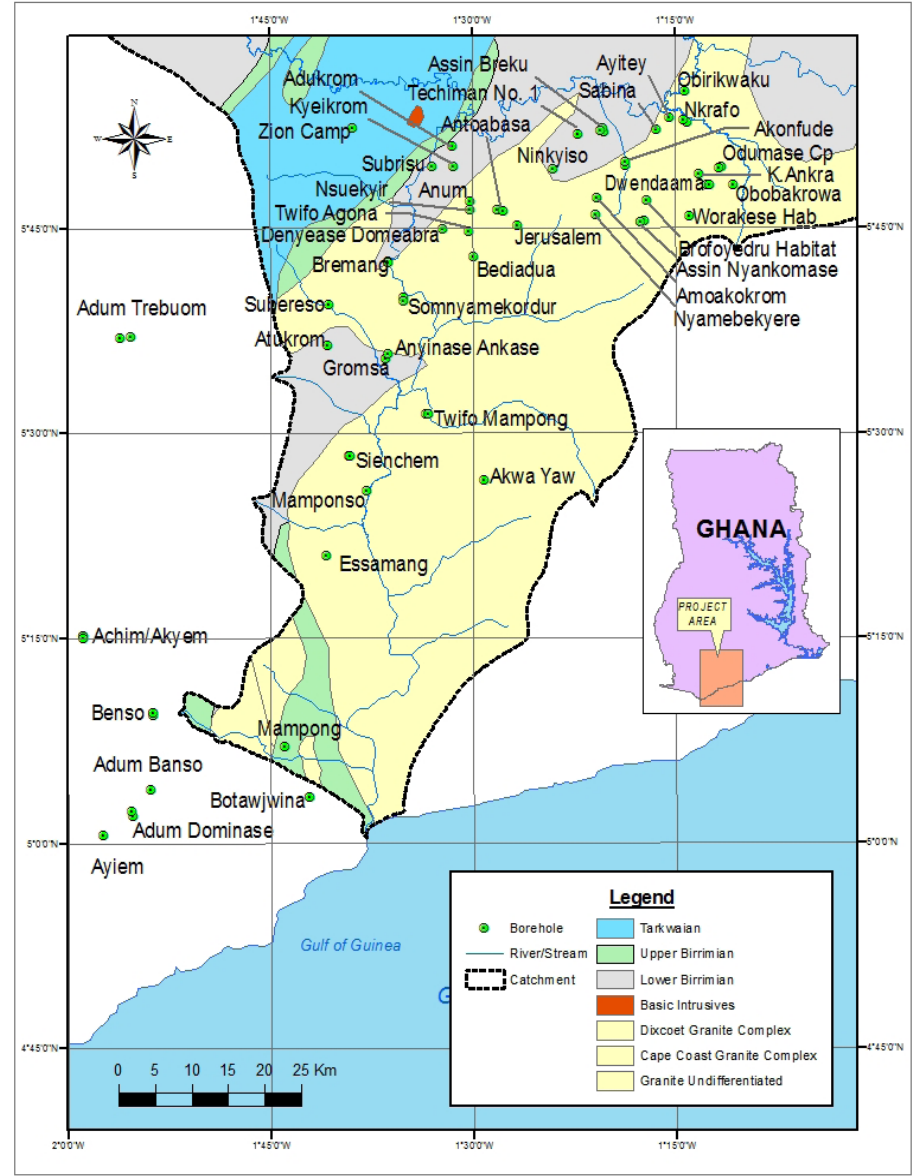

Fig.1: Map showing sampling communities and borehole locations

(Map of Ghana Insert) within the different geological settings. 


\section{Geology and soil}

The basin is predominantly underlain by granite rocks of the Cape Coast and Dixcove granitoids (Fig.1). Various portions of the basin are also underlain by metasediments of Birrimian and Tarkwain both of the precambian origin (Kesse, 1985). The basin is principally dominated by the forest ochrosoloxysol intergrades, which also contains more nutrients and are alkaline. They have rather variable drainage properties and therefore require protection against erosion. In the lower Pra nearer the coast, further classification includes the acid gloisol and coastal savannah soil groups (GWSC, 1989).

\section{Aquifer characteristics}

Borehole depths of the study area are generally shallow ranging between 30 to 96 metres, with a mean value of $44.42 \mathrm{~m}$. Borehole yield is generally low and largely variable, ranging from 0.4 to $51.7 \mathrm{~m}^{3} \mathrm{~h}^{-1}$ and mean value of 4.55 $\mathrm{m}^{3} \mathrm{~h}^{-1}$ with schist and granite aquifers having relatively higher yields (Tay et al., 2013, Dorleku 2013). The fractures in the rocks are generally open. The granite and schist rocks are exposed whilst; the Birimian and Takwian rocks have thick overburdens. The soils characteristically developed over the same kind of highly weathered parent material with lateritic to clayey topsoil layer and thickness which range from 4 to $14 \mathrm{~m}$, which may, however, extend further in some areas. The static water levels of the boreholes generally range from 0.4 to $22.4 \mathrm{~m}$ with a mean of $3.7 \mathrm{~m}$ (Tay et al., 2013).

\section{Land Uses}

The Pra Basin, in general, has considerable potential for development in agriculture, forestry, tourism, and mining, and provides livelihoods for many through these. Over 63\% of the population is engaged in the Agriculture and related sectors of the economy. Both commercial and subsistence agricultural activities are practiced, with cocoa being the main commercial crop (WRC, 2012). In the districts where large scale cocoa farming is practiced within the basin, annual returns in terms of family income are high and the standard of living is appreciable. In the Benso area of the Western region commercial oil palm plantation is prevalent (WRC, 2012). It was observed that small-scale palm oil industries are situated around Assin North and Benso areas because of large oil palm plantations (Dorleku, 2013).

\section{Sampling and analysis}

Water samples were collected from 65 boreholes in about 45 communities. The samples were collected two times for each season, January and April 2012 for the dry season and June and October for the wet season into previously sterile 1 Litre plastic bottles. About 500 litres of water was pumped out of the boreholes and the bottles rinsed with the borehole water just before each sample was taken. Temperature, $\mathrm{pH}$, and conductivity were measured in the field using Hach Sens ion 156 meter. The samples were transported to the CSIR-WRI laboratory in Accra at a temperature of about $4^{\circ} \mathrm{C}$ in an ice chest with ice cubes and kept in the refrigerator until analysed. Nitrate was determined by hydrazine reduction method using T60 UV spectrometer at wavelength of $520 \mathrm{~nm}$ (APHA, 1998). Phosphate and sulphate were determined by stannous chloride and turbidimetric method at a wavelength of $690 \mathrm{~nm}$ and $420 \mathrm{~nm}$ respectively (APHA, 1998). 


\section{Quality Control}

To ensure the reproducibility of the data, duplicate analysis was carried out for every batch of five samples. Blanks were analysed together with samples to check for contamination. Duplicates of $0.5,1.0$, and 10 $\mathrm{mg} / \mathrm{l}$ control standards from high-purity salts of nitrate, phosphate and sulphate respectively were prepared and analysed together with the samples to check for accuracy.

TABLE 1A

Seasonal nutrient concentration in individual boreholes in the basin

\begin{tabular}{|c|c|c|c|c|c|c|c|c|c|c|c|c|c|}
\hline \multirow{3}{*}{$\begin{array}{l}\text { Sample Source } \\
\text { Sabina }\end{array}$} & \multirow{2}{*}{\multicolumn{2}{|c|}{$\begin{array}{c}\text { pH } \\
\text { Sample ID }\end{array}$}} & \multirow{3}{*}{$\frac{\text { Dry }}{6.45}$} & \multicolumn{2}{|c|}{ Temp ${ }^{\circ} \mathrm{C}$} & \multicolumn{2}{|c|}{$\mathrm{EC} \boldsymbol{\mu} \mathrm{S} / \mathrm{cm}$} & \multicolumn{2}{|c|}{ PO4-P mg/l } & \multicolumn{2}{|c|}{$\mathrm{SO4}^{2-} \mathrm{mg} / 1$} & \multicolumn{2}{|c|}{$\mathrm{NO}_{3}-\mathrm{N} \mathrm{mg} / \mathrm{l}$} \\
\hline & & & & Wet & Dry & Wet & Dry & Wet & Dry & Wet & Dry & Wet & DryWet \\
\hline & $\mathrm{BH} 1$ & 4.9 & & 26.9 & 28.2 & 270 & 180 & 0.200 & 0.368 & 18.8 & 19.1 & 0.392 & 0.111 \\
\hline Ayitey & $\mathrm{BH} 2$ & 5.3 & 5.94 & 27.6 & 31.8 & 200 & 180 & 0.180 & 0.373 & 8.9 & 9.2 & 0.335 & 0.408 \\
\hline Nkrafo & $\mathrm{BH} 3$ & 5.2 & 6.87 & 27.1 & 30.1 & 360 & 260 & 0.060 & 0.278 & 4.7 & 31.3 & 0.192 & 0.011 \\
\hline Nkrafo & $\mathrm{BH} 4$ & 5.9 & 6.33 & 26.3 & 27.6 & 180 & 150 & 0.030 & 0.473 & 10.9 & 11.4 & 1.96 & 0.327 \\
\hline Obirikwaku & BH5 & 6.2 & 6.05 & 25.7 & 29.5 & 260 & 210 & 0.180 & 0.416 & 18.4 & 18.5 & 0.435 & 0.178 \\
\hline Odumasi & BH6 & 5.8 & 5.56 & 26.2 & 27.5 & 150 & 110 & 0.320 & 0.290 & 11.8 & 12.1 & 2.78 & 1.37 \\
\hline OdumasiCamp & $\mathrm{BH} 7$ & 6.2 & 5.67 & 26.9 & 27.7 & 300 & 200 & 0.410 & 0.303 & 6.2 & 30.9 & 0.666 & 0.353 \\
\hline Obobakokrowa & BH8 & 6.9 & 5.24 & 25.6 & 28.7 & 290 & 210 & 0.160 & 0.221 & 43.7 & 6.5 & 0.481 & 0.482 \\
\hline Dwedaama & BH9 & 6.4 & 6.26 & 25.7 & 27.3 & 240 & 180 & 0.560 & 0.234 & 35.0 & 35.0 & 0.243 & 0.071 \\
\hline Dwedaama & $\mathrm{BH} 10$ & 5.3 & 5.37 & 26.7 & 26.3 & 90 & 70 & 0.250 & 0.316 & 14.0 & 14.4 & 0.482 & 0.34 \\
\hline Worakase Habitat & BH11 & 5.8 & 4.73 & 26.5 & 25.7 & 80 & 80 & 0.540 & 0.293 & 7.4 & 7.3 & 2.03 & 1.55 \\
\hline Brofoyedru Habitat & BH12 & 5.2 & 4.47 & 28.2 & 25.6 & 120 & 100 & 0.570 & 0.501 & 17.9 & 17.6 & 0.759 & 0.05 \\
\hline Assin Nyankumase & BH13 & 6.9 & 4.90 & 29.2 & 27.6 & 470 & 70 & 0.160 & 0.496 & 55.6 & 56.9 & 3.22 & 0.073 \\
\hline Assin Nyankumase & BH14 & 7.3 & 5.09 & 28.5 & 28.5 & 180 & 380 & 0.351 & 0.288 & 18.1 & 18.9 & 0.582 & 1.29 \\
\hline Assin Nyankumase & BH15 & 7.9 & 4.69 & 28.1 & 27.8 & 70 & 160 & 0.643 & 0.342 & 18.7 & 18.1 & 5.01 & 1.45 \\
\hline Akonfudi & BH16 & 6.5 & 5.07 & 29.3 & 26.8 & 290 & 230 & 0.030 & 0.208 & 10.9 & 28.7 & 0.301 & 0.341 \\
\hline Akunfudi & BH17 & 6.3 & 5.14 & 29.1 & 27.2 & 500 & 360 & 0.180 & 0.298 & 18.4 & 25.6 & 0.677 & 0.391 \\
\hline Assin Breku(SDA) & BH18 & 6.0 & 6.41 & 30.5 & 26.4 & 140 & 260 & 0.410 & 0.257 & 4 & 43.2 & 0.753 & 0.053 \\
\hline Assin Breku(Gyidi) & BH19 & 6.3 & 5.53 & 28.7 & 27.3 & 290 & 230 & 0.210 & 0.373 & 43.7 & 6.14 & 0.986 & 0.518 \\
\hline Assin Breku & $\mathrm{BH} 20$ & 5.7 & 5.70 & 28.3 & 28 & 500 & 480 & 0.380 & 0.345 & 6 & 5.69 & 0.272 & 0.053 \\
\hline Techiman No 1 & $\mathrm{BH} 21$ & 6.1 & 5.12 & 29.1 & 26.9 & 60 & 60 & 0.400 & 0.278 & 31.7 & 12.8 & 0.188 & 0.451 \\
\hline Kwame Ankra & $\mathrm{BH} 22$ & 6.5 & 5.35 & 28.0 & 26.2 & 143 & 110 & 0.260 & 0.429 & 35.0 & 9.36 & 0.372 & 0.295 \\
\hline Ninkyiso & $\mathrm{BH} 23$ & 5.8 & 4.92 & 28.2 & 26.9 & 210 & 170 & 0.250 & 0.308 & 14.0 & 12.4 & 0.755 & 0.295 \\
\hline Amoakokrom & $\mathrm{BH} 24$ & 5.8 & 4.96 & 28.8 & 27.3 & 320 & 240 & 1.200 & 0.334 & 24.1 & 23.9 & 0.622 & 0.251 \\
\hline Nyamebekyere & $\mathrm{BH} 25$ & 5.6 & 5.63 & 27.2 & 26.8 & 170 & 130 & 1.900 & 0.010 & 7.4 & 3.6 & 0.732 & 0.462 \\
\hline Jerusalem & $\mathrm{BH} 26$ & 6.1 & 5.03 & 30.4 & 26.6 & 80 & 70 & 3.080 & 0.380 & 31.8 & 7.5 & 0.918 & 0.758 \\
\hline Antoabasa & $\mathrm{BH} 27$ & 5.9 & 5.34 & 30.2 & 28.3 & 170 & 140 & 0.490 & 0.632 & 21.9 & 31.6 & 0.702 & 0.197 \\
\hline Antoabasa & $\mathrm{BH} 28$ & 5.9 & 5.08 & 29.2 & 27.6 & 220 & 170 & 0.270 & 0.506 & 18.3 & 26.6 & 0.482 & 0.352 \\
\hline Bedidua & $\mathrm{BH} 29$ & 6.5 & 5.15 & 28.8 & 28.3 & 220 & 170 & 0.480 & 0.458 & 10.3 & 18.1 & 0.469 & 0.114 \\
\hline Anum & ВH30 & 6.0 & & 28.3 & & 270 & & 0.340 & & 16.7 & & 0.198 & \\
\hline Kyeikrom & ВН31 & 5.6 & $\overline{5} .70$ & 31.6 & $\overline{3} 1$ & 150 & $\overline{120}$ & 0.340 & $\overline{0} .300$ & 3.6 & $\overline{5} .2$ & 0.37 & 0.43 \\
\hline Adukrom & BH32 & 5.9 & - & 27.1 & & 140 & & 0.340 & & 22.2 & & 0.717 & \\
\hline Subrisu & ВH33 & 6.0 & - & 27.0 & - & 240 & - & 0.140 & - & 24.2 & - & 0.28 & $\overline{0} .114$ \\
\hline
\end{tabular}


TABLE 1B

Seasonal nutrient concentrations in individual boreholes continued.

\begin{tabular}{|c|c|c|c|c|c|c|c|c|c|c|c|c|c|}
\hline Nsukyir & BH34 & 5.9 & 5.4 & 26.5 & 27.3 & 170 & 170 & 0.670 & 0.733 & 22.2 & 22.0 & 0.499 & 0.205 \\
\hline Denyease Domeabra & BH35 & 5.6 & 5.98 & 28.0 & 27.1 & 220 & 160 & 0.740 & 0.78 & 9.9 & 15.5 & 0.328 & 0.123 \\
\hline Twifo Mampong & BH36 & 6.0 & 4.24 & 28.6 & 29.6 & 279 & 220 & 0.669 & 0.532 & 23.8 & 77.9 & 0.671 & 0.255 \\
\hline Twifo Mampong & BH37 & 6.4 & 5.90 & 30.7 & 29.1 & 1140 & 590 & 0.558 & 0.92 & 13.6 & 77.8 & 0.36 & 0.16 \\
\hline Akwa Yaw & BH38 & 6.6 & & 29.3 & & 130 & & 0.161 & & 10.4 & & 0.961 & \\
\hline Bremang & BH39 & 6.3 & $\overline{6} .18$ & 29.8 & $\overline{3} 1.2$ & 310 & $\overline{2} 60$ & 0.271 & $\overline{0} .109$ & 22.6 & $\overline{7} 6.2$ & 0.339 & 0.079 \\
\hline Bremang & BH40 & 6.0 & 6.06 & 29.2 & 31.4 & 240 & 200 & 0.268 & 0.938 & 3.6 & 44.6 & 0.412 & 0.142 \\
\hline Twifo Agona & BH41 & 5.9 & 4.96 & 28.8 & 29.3 & 190 & 140 & 1.990 & 0.175 & 7.5 & 22.4 & 0.205 & 0.091 \\
\hline Somnyamekordru & $\mathrm{BH} 42$ & 5.3 & 6.24 & 26.8 & 28.1 & 710 & 410 & 0.669 & 0.866 & 13.6 & 13.8 & 0.242 & 0.146 \\
\hline Somnyamekordru & BH43 & 6.3 & 5.95 & 27.4 & 28.4 & 824 & 130 & 0.558 & 0.137 & 10.4 & 10.4 & 0.369 & 0.609 \\
\hline Atu Krom & BH44 & 5.6 & 4.95 & 29.5 & 28.1 & 350 & 240 & 0.429 & 0.156 & 58.7 & 58.2 & 0.255 & 0.163 \\
\hline Subresu & BH45 & 6.1 & 5.29 & 28.1 & 28.4 & 190 & 200 & 0.156 & 0.115 & 62.1 & 61.9 & 0.294 & 0.071 \\
\hline Gromsa & BH46 & 6.9 & 4.40 & 28.9 & 27.1 & 190 & 150 & 0.271 & 0.509 & 75.7 & 23.6 & 0.346 & 0.23 \\
\hline Anyinase Ankase & BH47 & 6.4 & 4.66 & 28.5 & 26.3 & 100 & 90 & 0.268 & 0.488 & 9.1 & 9.7 & 0.387 & 0.141 \\
\hline Semchem & BH 48 & 6.6 & 4.88 & 29.9 & 29.6 & 560 & 200 & 0.362 & 0.491 & 91 & 77.5 & 0.349 & 0.388 \\
\hline Semchem & BH49 & 6.1 & 4.56 & 27.2 & 27.6 & 400 & 300 & 0.437 & 0.506 & 31.9 & 31.2 & 0.304 & 0.151 \\
\hline Mampong & BH50 & 5.3 & 5.02 & 26.4 & 27.6 & 110 & 100 & 0.502 & 0.707 & 1.6 & 32.7 & 0.718 & 0.451 \\
\hline Essamang & BH51 & 5.8 & 5.6 & 26.7 & 27.6 & 60 & 50 & 0.210 & 0.121 & 32.2 & 14.4 & 2.24 & 0.038 \\
\hline Achim/Akyem & BH52 & 6.5 & 6.5 & 26.8 & 26.4 & 423 & 417 & 0.37 & 0.34 & 26.9 & 23.9 & 0.33 & 0.32 \\
\hline Achim/Akyem & BH53 & 6.7 & 6.5 & 27.2 & 26.6 & 371 & 368 & 0.33 & 0.32 & 27.2 & 25.2 & 0.15 & 0.17 \\
\hline Achim/Akyem & BH54 & 6.3 & 6.1 & 26.1 & 27.2 & 453 & 449 & 0.32 & 0.33 & 35.4 & 32.9 & 2.08 & 2.01 \\
\hline Ayiem & BH55 & 5.7 & 5.9 & 28.5 & 28.5 & 140 & 137 & 0.82 & 0.75 & 76.3 & 77.1 & 0.59 & 0.62 \\
\hline Botawjwina & BH56 & 6.7 & 6.5 & 29.2 & 28.8 & 615 & 605 & 0.29 & 0.35 & 62.4 & 69.4 & 0.26 & 0.32 \\
\hline Botawjwina & BH57 & 6.4 & 6.2 & 28.7 & 28.8 & 923 & 906 & 0.33 & 0.24 & 96.2 & 79.1 & 0.54 & 0.49 \\
\hline Benso & BH58 & 5.6 & 6.3 & 27.8 & 27.5 & 156 & 521 & 0.44 & 0.42 & 13.9 & 78.9 & 0.28 & 2.61 \\
\hline Benso & BH59 & 5.2 & 5.4 & 27.3 & 28.1 & 412 & 153 & 0.42 & 0.37 & 72.3 & 14.9 & 2.71 & 0.50 \\
\hline Benso & BH60 & 6.1 & 5.6 & 29.2 & 27.4 & 527 & 403 & 0.57 & 0.38 & 73.9 & 70.3 & 0.40 & \\
\hline Adum Banso & BH61 & 5.6 & 5.8 & 26.5 & 27.8 & 411 & 402 & 0.34 & 0.33 & 52.4 & 50.4 & 0.34 & $\overline{0} .44$ \\
\hline Adum Dominase & BH62 & 5.5 & 5.7 & 28.2 & 28.2 & 343 & 339 & 0.44 & 0.40 & 21.6 & 21.6 & 0.63 & 0.67 \\
\hline Adum Dominase & BH63 & 5.9 & 5.7 & 28.7 & 27.8 & 93.4 & 90.9 & 0.40 & 0.39 & 14.2 & 13.9 & 0.73 & 0.69 \\
\hline Adum Trebuom & BH64 & 6.1 & 6.0 & 27.1 & 26.6 & 196 & 188 & 0.53 & 0.58 & 24.2 & 22.5 & 0.51 & 0.55 \\
\hline Adum Trebuom & BH65 & 6.4 & 6.6 & 28.3 & 26.9 & 333 & 327 & 0.41 & 0.40 & 22.2 & 20.2 & 0.36 & 0.30 \\
\hline Min Value & & 4.9 & 4.24 & 25.6 & 25.6 & 60 & 50 & 0.030 & 0.010 & 1.6 & 3.6 & 0.15 & 0.011 \\
\hline Max Value & & 7.9 & 6.87 & 31.6 & 31.8 & 1140 & 906 & 3.080 & 0.938 & 96.2 & 79.1 & 5.01 & 2.61 \\
\hline
\end{tabular}

TABLE 2

Mean Dry Season statistical summary of data in $\mathrm{mg} / \mathrm{l}-$ unless specified

\begin{tabular}{lcccccc}
\hline $\mathrm{n}=65$ & MIN & MAX & Mean & Median & SD & WHO \\
\hline $\mathrm{pH}(\mathrm{pH}$ units $)$ & 4.90 & 7.90 & 6.06 & 6.00 & 0.54 & $6.50-8.50$ \\
$\mathrm{EC}(\mu \mathrm{s} / \mathrm{cm})$ & 60.0 & 1140 & 291 & 240 & 208 & - \\
$\mathrm{NO}_{3-}^{-} \mathrm{N}$ & 0.15 & 5.01 & 0.75 & 0.47 & 0.85 & 10 \\
$\mathrm{PO}_{4}{ }^{3-}-\mathrm{P}$ & 0.03 & 3.08 & 0.47 & 0.36 & 0.20 & - \\
$\mathrm{SO}_{4}{ }^{2-}$ & 1.6 & 96.2 & 27.0 & 18.8 & 22.7 & 250 \\
\hline
\end{tabular}


TABLE 3

Mean Wet Season statistical summary of data in mg/l-unless specified.

\begin{tabular}{lcccccc}
\hline $\mathrm{n}=65$ & MIN & MAX & Mean & Median & SD & WHO \\
\hline $\mathrm{pH}(\mathrm{pH}$ unit $)$ & 4.24 & 6.87 & 5.5 & 5.59 & 0.63 & $6.50-8.50$ \\
$\mathrm{EC}(\mu \mathrm{s} / \mathrm{cm})$ & 50 & 906 & 236 & 188 & 159 & - \\
$\mathrm{NO}_{3}^{-}-\mathrm{N}$ & 0.011 & 2.61 & 0.43 & 0.32 & 0.49 & 10 \\
$\mathrm{PO}_{4}^{3-} \mathrm{P}$ & 0.010 & 0.938 & 0.40 & 0.37 & 0.20 & - \\
$\mathrm{SO}_{4}^{2-}$ & 3.60 & 79.1 & 30.1 & 22.4 & 23.2 & 250. \\
\hline
\end{tabular}

TABLE 4

Statistical summary of data from the Basin

\begin{tabular}{lccccccc}
\hline $\mathrm{n}=65$ & Min. & Max. & Mean & Median & Stdev. & P-Value & W.H.O(2004) \\
\hline $\mathrm{Temp}\left({ }^{\circ} \mathrm{C}\right)$ & 25.6 & 31.8 & 28 & 27.9 & 1.33 & - & - \\
$\mathrm{PH}(\mathrm{pHunits})$ & 4.24 & 7.90 & 5.80 & 5.79 & 0.58 & - & $6.5-8.0$ \\
$\mathrm{EC}(\mu \mathrm{s} / \mathrm{cm})$ & 55 & 1140 & 264 & 214 & 183 & - & - \\
$\mathrm{NO}_{3}^{-}-\mathrm{N}$ & 0.08 & 5.01 & 0.59 & 0.39 & 0.67 & 0.011 & 10 \\
$\mathrm{PO}_{4}{ }^{3-}-\mathrm{P}$ & 0.01 & 3.08 & 0.44 & 0.36 & 0.34 & 0.225 & - \\
$\mathrm{SO}_{4}{ }^{2-}$ & 1.6 & 96.2 & 28.5 & 20.6 & 22.9 & 0.443 & 250 \\
\hline
\end{tabular}




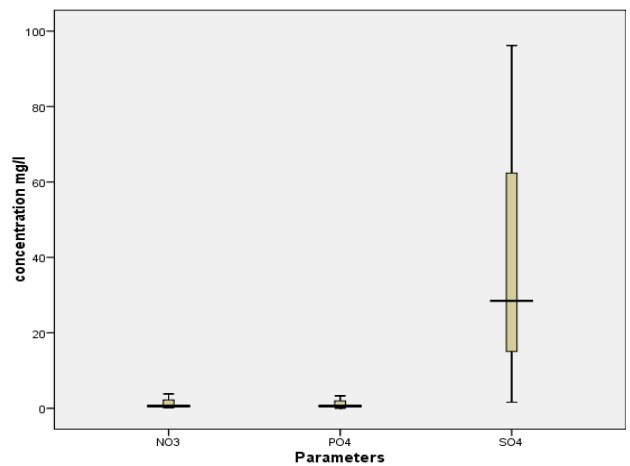

Fig. 2: Box plot of nutrient concentrations of boreholes in the Pra basin

\section{Results and Discussion}

Table 1 represents the mean seasonal nutrient concentrations in groundwater within the Lower Pra Basin. Tables 2 and 3 represent the statistical summary of dry and wet seasons respectively whilst Table 4 shows the summary of statistical data from the basin.

The results show that the mean concentration of the parameters as compared to the WHO(2006) guideline values are low and do not pose an immediate threat to human health.

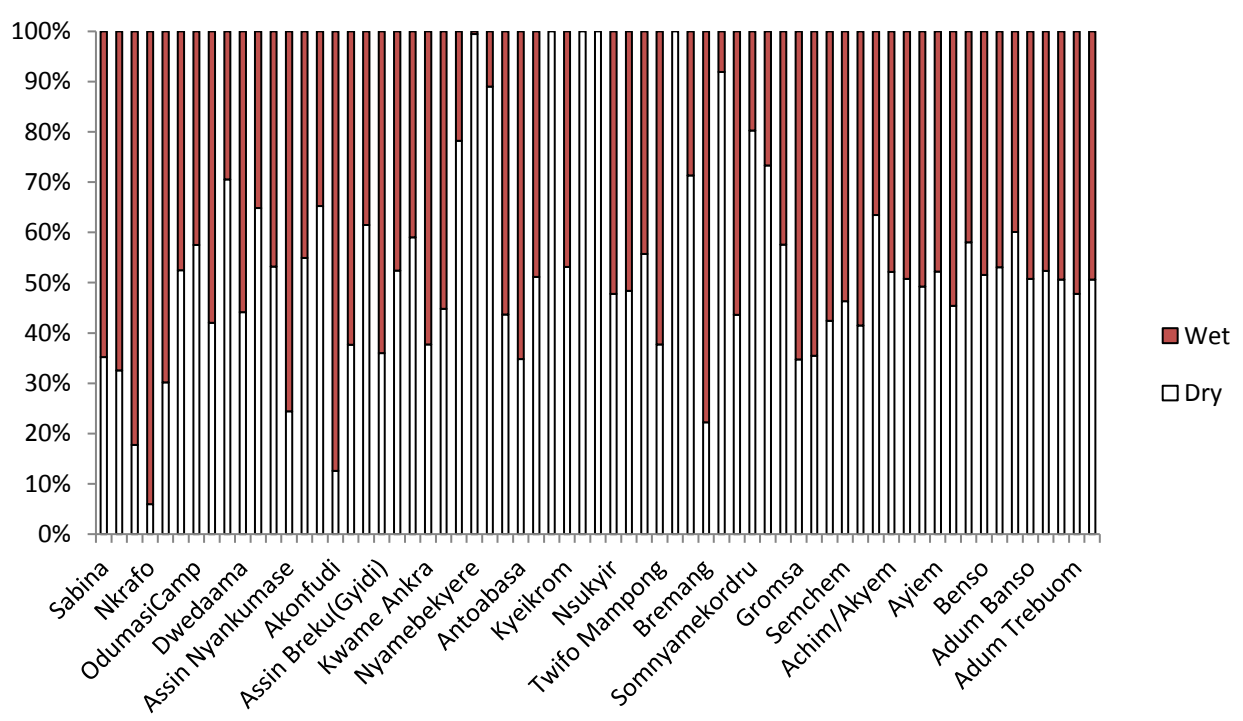

Fig. 3: \% stacked Histogram of dry and wet seasons for Phosphate in the basin. 


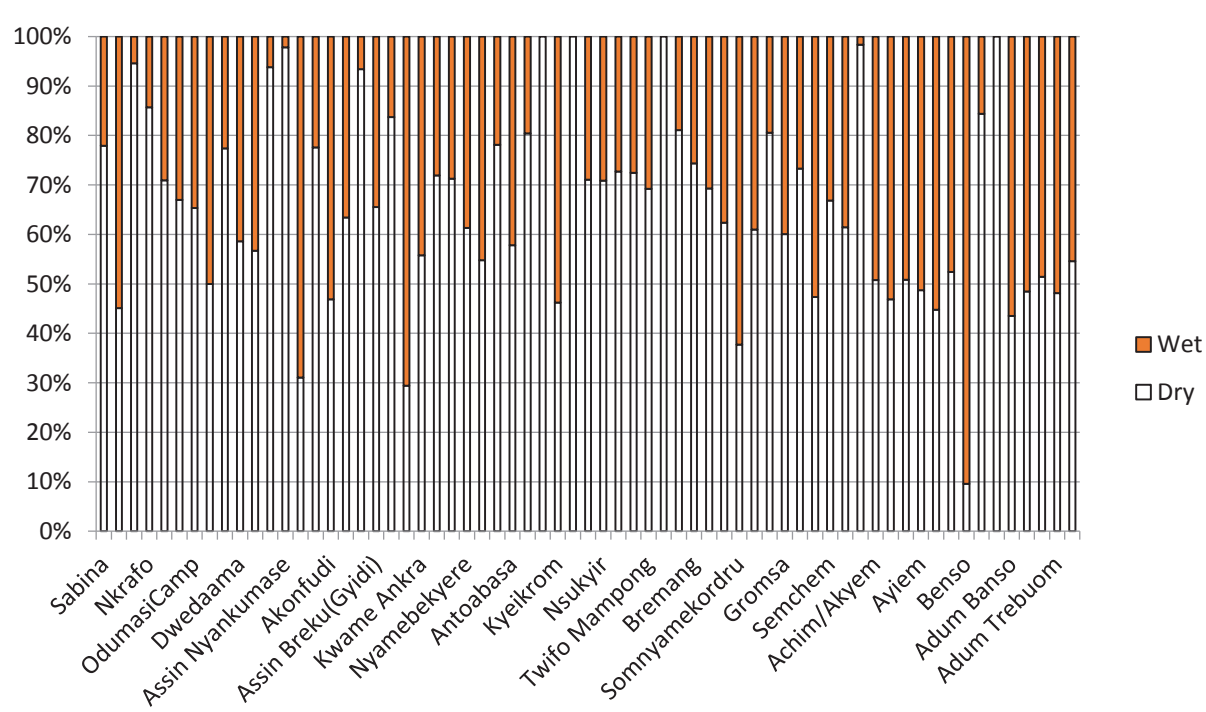

Fig. 4: \% stacked Histogram of dry and wet seasons for Nitrate in the basin.

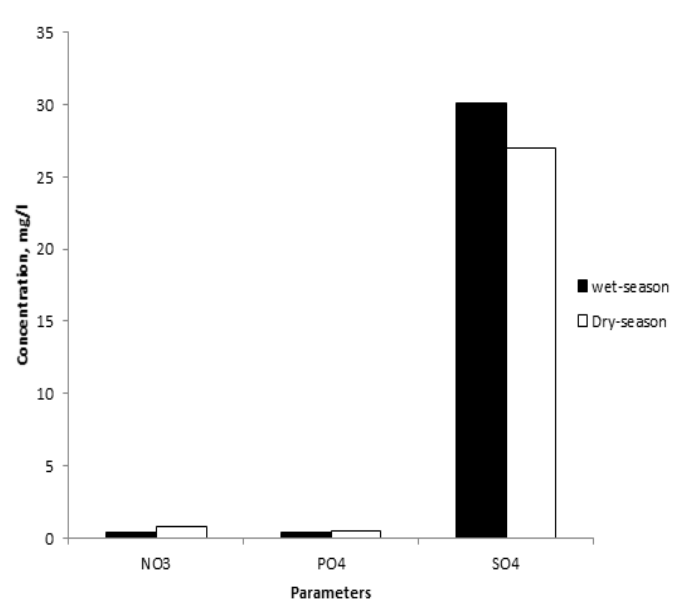

Fig. 5: Bar graph of mean wet and dry season nutrient concentrations.

The concentration of each parameter as related to each other is illustrated by the box plot in fig 2. It can be seen from the box plot that sulphate is largely variable and have relatively large range as compared to the other two (which are nutrients).

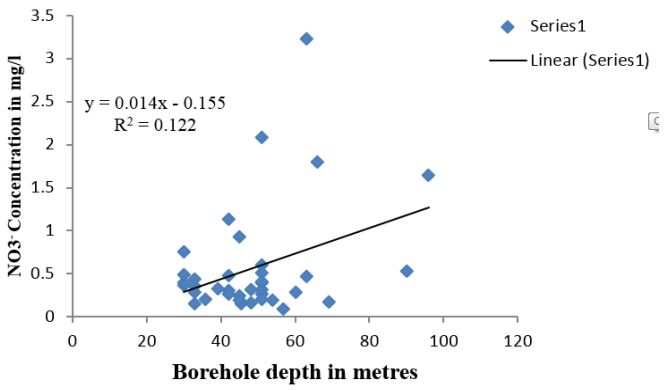

Fig. 6: Scatter plot showing correlation between borehole depth and $\mathrm{NO}_{3}{ }^{-}$concentration.

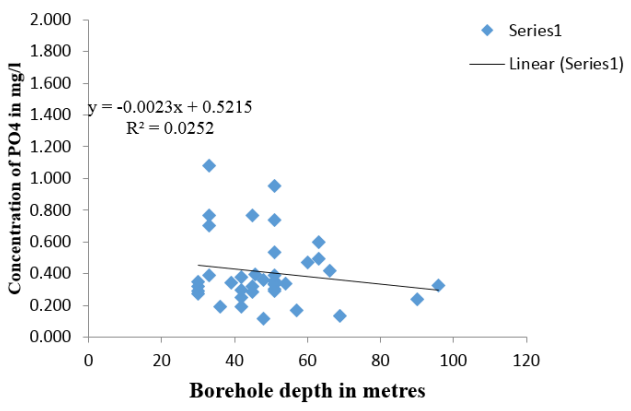

Fig. 7: Scatter plot showing correlation between borehole depth and $\mathrm{PO}_{4}^{3-}$ Pconcentration. 


\section{Nitrate}

Nitrate is often a major health concern in the developed countries as a result of welldocumented pollution of groundwater from the use of nitrate-based fertilizers and a wide spectrum of synthetic pesticides for improving crop yield, leading to methaemoglobinaemia and stomach cancers (Edmunds \& Smedley, 1996; WHO, 2011). Nitrate is very soluble and although some may be used by plants, much of the dissolved nitrate escapes unused into deeper parts of the soil and groundwater and can be toxic to humans at concentrations between 10 to15 mg/l (Egboka et al., 1989). Dry season values range from 0.15 to $5.01 \mathrm{mg} / 1$ with the wet season recording values between 0.011 and $2.61 \mathrm{mg} / 1$ (Tables 2 and 3). ). None of the boreholes recorded values above the W.H.O (2006) value of $10 \mathrm{mg} / \mathrm{l}$. However, the highest value of $5.01 \mathrm{mg} / \mathrm{l}$ was recorded in the dry season at Assin Nyankumasi (BH 15). Field observations within the study area indicate that the borehole located at Assin Nyankumase (BH15) is sited very close to a public latrine, which might have contributed to the relatively high nitrate value. The highest mean wet season value $(2.60 \mathrm{mg} / \mathrm{l})$ was recorded at Benso (BH58), where there are commercial oil palm plantations and therefore might have been influenced by fertilizer usage. Ahialey et al, (2010), recorded values between 0.089 $\mathrm{mg} / \mathrm{l}$ and $9.03 \mathrm{mg} / \mathrm{l}$ within the basin. The mean and median values recorded for the dry season were 0.75 and $0.47 \mathrm{mg} / \mathrm{l}$ respectively whilst that of the wet season recorded values of 0.43 and $0.32 \mathrm{mg} / 1$ respectively (tables 2 and 3 ) and further shown by the bar graph (fig 4). Mean dry season values were generally higher than wet season values, Fig 5 . The relative lower values for the wet season might have been the result of rainfall precipitation and recharging of aquifers by freshwater culminating in the dilution of concentration levels. There is a significant difference between the dry and wet season values $(p<0.05)$, Table 4 . There was, however, a very weak positive correlation $\left(\mathrm{R}^{2}\right.$ $=0.122$ ) between borehole depth and nitrate concentration, Fig 6, indicating that nitrate concentration in the aquifers might be as a result of natural biogeological processes, rather than from anthropogenic sources ie fertilizer and synthetic pesticide inputs. Concentrations of nitrate generally decrease with good depth (USGS, 2010). This is because (1) recharge of deep, old groundwater most likely occurred when anthropogenic nitrogen inputs were relatively low; (2) the amount of time required for microbial processes such as denitrification to take place increases as water moves downward through the aquifer; and (3) deep groundwater is commonly a mixture of water that has moved along flow paths that originate in areas of differing land uses and nitrogen inputs (USGS, 2010). Aquifers within the basin are not under threat from agriculture activities.

\section{Phosphate}

Phosphorus is a nutrient required by all organisms for the basic processes of life. Weathering of certain minerals particularly apatite provides a natural source of dissolved phosphorus in groundwater (Hitchon et al., 1999). Phosphorus in natural waters is usually found in the form of phosphates $\left(\mathrm{PO}_{4}^{3-}\right)$ (UNEP GEM, 2006). Orthophosphates applied to agricultural or residential cultivated land as fertilizers are carried into surface waters with storm runoff which eventually ends up in groundwater (APHA, 1998). Dry season values ranged from 0.03 to $3.08 \mathrm{mg} / 1$ whilst the wet season recorded values between 0.010 and $0.938 \mathrm{mg} / \mathrm{l}$. The W.H.O has not given any guideline value for phosphate, but 
the U.SEPA recommended a safe value of $2.5 \mathrm{mg} / \mathrm{l}$. Only one borehole (BH26) with phosphate concentration $3.08 \mathrm{mg} / \mathrm{l}$ in the dry season recorded value above the U.SEPA recommended a value of $2.5 \mathrm{mg} / \mathrm{l}$. Mean and median values recorded for the dry season were 0.47 and $0.36 \mathrm{mg} / 1$ respectively and that of wet season was 0.40 and $0.37 \mathrm{mg} / 1$ respectively. There is no significant difference between dry and wet season values ( $>0.05)$ (Table 4 and Fig 5). Hence natural geologic sources might have a greater influence on concentrations in groundwater than anthropogenic sources. Concentrations of dissolved phosphorus (DP) in groundwater typically are low because phosphorus tends to sorb to soil and aquifer sediments and is not readily transported into groundwater (Holman et al. 2008). There is a very weak negative correlation between borehole depth and phosphate concentration, $\left(R^{2}=0.025\right)$, Fig 7 within the Pra basin. United State Geological Survey (USGS), 2010; Dubrovsky et al. 2010 reported that dissolved phosphorus concentrations in groundwater showed no correlation to fertilizer and manure use in agricultural areas in California and other regions; more so, there was similarity of concentrations in both shallow and deep groundwater and therefore concluded that natural geologic sources of phosphorus may have a greater influence on concentrations in groundwater than do human-derived sources from activities on the land surface. Hence natural geologic factors might have contributed to phosphorus levels in the aquifers within the Pra basin.

\section{Sulphate}

Sulphate is an abundant ion in the earth's crust and high concentrations may be present in winter due to leaching of gypsum, sodium sulphate, and some shales (UNEP-GEM,
2006). As a result of oxidation of pyrites and gypsum mine drainage may contain high concentrations of sulphate, leading to groundwater contamination. Fertilizers and natural sources, such as volcanoes also contribute to sulphate presence in groundwater (MPCA, 1999). The dry season recorded 27.0 and $18.8 \mathrm{mg} / \mathrm{l}$ for mean and median respectively whilst that of the wet season was 30.1 and $22.4 \mathrm{mg} / \mathrm{l}$ respectively. Higher mean wet season value is in agreement with literature as stated earlier. Sulphate values for both seasons ranged between 1.6 to $96.2 \mathrm{mg} / \mathrm{l}$ within the basin, and thus below the W.H.O (2006) permissible limit of 250mg/l (Table 4). There is no significant difference however, between the dry season and wet season values with $\mathrm{P}>0.05$, (Table 4). Acid mine drainage might not yet be contributing significantly to the aquifers within the basin.

\section{Conclusion}

Nitrate values recorded in the basin were low, with mean dry and wet season values of 0.75 and $0.43 \mathrm{mg} / \mathrm{l}$ respectively, far below the W.H.O recommended a value of 10.0 $\mathrm{mg} / \mathrm{l}$ for drinking water. The contribution of synthetic fertilizers and other anthropogenic activities does not seem to pose a threat to groundwater in the basin. There was a very weak positive correlation between borehole depth and nitrate concentration, indicating that nitrate concentration in the aquifers might be predominantly as a result of natural geological processes. Mean phosphorus value for both seasons was $0.44 \mathrm{mg} / \mathrm{l}$, even though one borehole recorded an elevated mean dry season value of $3.08 \mathrm{mg} / \mathrm{l}$ which is above the USEPA recommended value of $2.5 \mathrm{mg} / \mathrm{l}$. There is a very weak negative correlation between borehole depth and phosphate concentrations. Hence natural geologic sources might have a greater 
influence on concentrations in groundwater than anthropogenic sources. Phosphorus does not pose a threat to aquifers in the basin. Even though the wet season recorded higher values for sulphate than the dry season, there was no significant difference between them. Sulphate values for both seasons ranged between 1.6 to $96.2 \mathrm{mg} / \mathrm{l}$ in the basin, all below the W.H.O permissible limit of $250 \mathrm{mg} / \mathrm{l}$. Geological processes such as leaching of certain rocks might be the contributing factor in the aquifers rather than fertilizer sources.

\section{References}

Ahialey, E. K, Serfoh-Armah, Y., \& Kortatsi, B. K. (2010) Hydrochemical analysis of groundwater in the Lower Pra Basin. J. Water Resource and Protection 2, $864-871$.

ApHa (1998) "Standard Method for the Examination of Water and Wastewater," 20th Edition, American Public Health Association, Washington D.C. 1998.

Asamoah, D. N. \& Amorin, R. (2011) Assessment of the quality of bottled/sachet water in the Tarkwa-Nsuaem Municipality(TM) of Ghana. Research Journal of Applied ScienceEngineering and Technology 3, $377-385$.

BAIRD, C. \& CANn, M. (2008) Environmental Chemistry W.H. Freeman and Company Fourth edition, New York Press. $301-302$.

CAfÉ, (2017) The Centre for Agriculture, food and the Environment, University of Massachusetts Amherst.https://ag.umass.edu/crops-dairylivestock-equine/fact-sheets/nutrients-water-quality. Acessed on 4th April, 2017.

Dickson, K. B., \& Benneh, G. (2004) A New Geography of Ghana. Fifth impression, Revised edit. Longman, London

Dorleku, M. (2013) 'Groundwater Contamination With Toxic Metals Through Smallscale Mining Within the Lower Pra Basin', Ghana.
MPhil. Thesis, University of Ghana, Legon Accra, Ghana.

Dubrovsky, N. M., Burow, K. R., Clark, G. M., et al., (2010) The quality of our Nation's waters-Nutrients in the Nation's streams and groundwater, 1992-2004: US Geol Surv Circ $1350,174 \mathrm{p}$

Egboka, B. C., Nwankwor, G. I., Orajaka, I. P. et al., (1989) Principles and Problems of Environmental Pollution of Groundwater Resources with Case Examples from Developing Countries. Environmental Health Perspectives 83, $39-68$

Fuhrer, G. J., Gilliom, R. J., Hamilton, P. A., et al., (1999) The quality of our nation's water: nutrients and pesticides. US Geol Surv Circ $1225,82 \mathrm{p}$.

Hitchon, B., Perkins, H. E. \& Gunter,W. D. (1999) Introduction to Ground Water Geochemistry. Geoscience Publishing Ltd., Sherwood Park, Alberta, Canada. pp 310.

Holman, I. P., Whelan, M. J., Howden, N. J .K, et al., (2008) Phosphorus in groundwater - an overlooked contributor to eutrophication? Hydrol Processes 22, 5121 5127.

Hynds, P. D., Thomas, M. K., \& Pintar, K. D. M. (2014) Contamination of groundwater systems in the US and Canada by Enteric Pathogens, 1990-2013: a review and pooled-analysis. PLOS ONE 9 (5), e93301. doi:10.1371/ journal.pone.0093301.

Kesse, G. O. (1985) The mineral and rock resources of Ghana. A.A/ Balkema, Rotterdam/Boston.

Kortatsi, B. K. (2006) Concentration of Trace Metals in Boreholes in the Ankobra Basin, Ghana. West African Journal of Applied Ecology 10, 73 - 87.

MPCA (1999) Minnesota Pollution Control Agency, Environmental Outcomes Division 
Munn, M. D., Nolan, B. T., Puckett, L. J., et al., (2010) The quality of our Nation's waters Nutrients in the Nation's streams and groundwater, 1992 - 2004: US Geol Surv

Circ 1350, 174 p.

Prüss-Üstün, A., Bos, R., Gore, F. \& Bartram, J. (2008) Safer Water, Better Health: costs, benefits and sustainability of interventions to protect and promote health. Geneva: World Health Organization.

Smedley, P. L., Ednunds, W. M., West, J. M., et al., (1995) Vulnerability of Shallow Groundwater Quality due to Natural Geochemical Environment. Health Problems related to groundwater in the Obuasi and Bolgatanga areas, Ghana British Geological Survery, $130 \mathrm{pp}$ (WC/95/043 Vol. 2) (unpublished)

Tay, C., Hayford, E., Hodgson, I. O., et al., (2013) "Hydrochemical appraisal of groundwater evolution within the Lower Pra Basin, Ghana: a hierarchical cluster analysis (HCA) approach".Environ Earth Sci DOI 10.1007/ s12665-014-3644-4.
TAY, C. (2015) Hydrogeochemical Processes Influencing Groundwater Quality Within The Lower Pra Basin, Ghana. PhD Thesis, University of Ghana, Legon-Accra, Ghana

UNITED NATIONS ENVIRONMENT PROGRAMME (UNEP) (2006) Global Environment Monitoring System/Water Programme.

USGS (2010) Nutrients in the Nation's Streams and Groundwater, 1992 - 2004. National Water-Quality Assessment Program, U.S. Geological Survey, Reston, Virginia

WHO (2006). Guidelines for drinking-water quality, 3rd ed.Vol.1. Recommendations, World Health Organization, Geneva.

WHO (2011) Nitrate and Nitrite in Drinking-water Background document for development of WHO Guidelines for Drinking-water Quality. World Health Organization, Geneva.

WATER RESOURCES COMMISSION (WRC), (2012) Pra River Basin-Integrated Water Resources Management Plan, June 2012.

Received 01 Nov 18; revised 02 Jul 19. 